\title{
The Entrepreneurial Orientation of Immigrant Entrepreneurs in South Africa
}

\author{
Olawale Fatoki \\ Department of Business Management, Turfloop campus, University of \\ Limpopo, Limpopo Province, South Africa \\ Email: Olawale.fatoki@ul.ac.za \\ Olabanji Oni \\ Department of Business Management, Turfloop campus, University of \\ Limpopo, Limpopo Province, South Africa \\ Email: Olabanji.oni@ul.ac.za
}

Doi:10.5901/mjss.2014.v5n20p497

\section{Abstract}

The objective of this study was to measure the entrepreneurial orientation of immigrant entrepreneurs in South Africa. Data was collected through the use of self-administered questionnaires in a survey. The study focused on immigrant entrepreneurs from West Africa specifically, Nigerians, Ghanaians and Senegalese that are business owners in the retail sector and have been in business for at least five years. Because of the difficulty in obtaining the population of immigrant entrepreneurs in the study area, purposive and snowball sampling methods were used. The results indicated that immigrant entrepreneurs are adept at introducing new product lines and also making changes to their product lines. This suggests that immigrant entrepreneurs are innovative. The results also showed that immigrant entrepreneurs are proactive as they have the tendency to be ahead of others in introducing new products. In additions, immigrant entrepreneurs have a strong preference for high risk projects with chances of high return.

Keywords: immigrant, entrepreneurs, entrepreneurial orientation, South Africa

\section{Introduction}

Pendleton et al. (2006) point out that South Africa is a rainbow nation composed of various racial groups from all facets of the earth. Following independence in 1994, an increasing number of immigrants migrated to South Africa from other African countries and from other continents. Aguilar (2013) points out that immigrant entrepreneurs make significant contributions to the economy of a country. Immigrant entrepreneurs are business owners and create jobs. Immigrant entrepreneurs increase a nation's capacity to develop new ideas and contribute to competitiveness in the business landscape. Fairlie and Lustrum (2013) remark that immigrants are highly entrepreneurial. Immigrant entrepreneurs are essential for economic growth and innovation.

South Africa suffers from a high rate of unemployment with an official unemployment rate of $25.2 \%$ (Statistics South Africa, 2014). In addition, the rates of poverty and inequality are very high in South Africa (Bhorat and Van der Westhuizen (2012). According to Tengeh et al. (2012), immigrant entrepreneurs employ South Africans in their businesses. Thus, immigrant entrepreneurs contribute to the growth and development of South Africa. Through the creation of jobs, immigrant entrepreneurship is one of the solutions to poverty and income inequality and unemployment in South Africa. Wayland et al. (2012) agree that through investments and business formation, immigrants can become a major source of job creation in the host country.

Collins (2008) points out that the business failure rates are high for small businesses, including immigrant enterprises. Engelen, (2002) notes that immigrant entrepreneurs are overrepresented in certain business areas such as retail and restaurant trades. Immigrant entrepreneurs tend to copy the entrepreneurial strategies of their compatriots. Accordingly, immigrant entrepreneurs are very active in markets that have a low or limited growth potential and are easily accessible for newcomers. This suggests that their survival as entrepreneurs is precarious due to the crowding effects. Engelen (2002) finds that failure rate of business is higher amongst immigrant compared to non-immigrant entrepreneurs. Furthermore, immigrant entrepreneurs suffer from low profitability, long working hours, high competition and a high degree of business informality. According to Aktan and Bulut (2008) and Chen et al. (2008), today's businesses are faced 
with a rapidly changing and fast-paced competitive environment. To cope with such challenges an entrepreneurial approach to strategy making may be vital for organisational success. Van Geenhuizen et al. (2008) note that entrepreneurial orientation (EO) has emerged as a possible antidote to the problems facing businesses that wish to achieve a sustained competitive advantage. Rauch et al. (2009) analyse fifty one studies (involving fourteen thousand, two hundred and fifty nine companies) on the relationship between entrepreneurial orientation and business performance. The results indicate that the correlation of EO with performance is moderately large. This suggests that entrepreneurial orientation can be highly significant in improving the performance and reducing the failure rate of immigrant entrepreneurs in South Africa.

\section{Objective of the Study}

The objective of this study is to measure the entrepreneurial orientation of immigrant entrepreneurs in South Africa. The literature significantly supports a positive relationship between entrepreneurial orientation and firm performance. Entrepreneurial orientation can help immigrant entrepreneurs to achieve a sustained competitive advantage in the market place.

\section{Literature Review}

\subsection{Immigrant entrepreneurship}

Immigrant entrepreneurship is described as the process by which an immigrant establishes a business in a host country (or country of settlement) which is not the immigrant's country of origin (Dalhammar 2004). According to Aaltonen and Akola (2014), an immigrant entrepreneur is a person who has immigrated to a new country and started a business there. Vinogradov (2008) describes an immigrant entrepreneur as a person who arrives in the country and starts a business for the purpose of economic survival. Kahn et al. (2013) point out that an immigrant entrepreneur is a business owner, having foreign origin, who is involved into the act of economic innovation, organization creation and profit-seeking in the market sector. Aaltonen and Akola (2014) point out that immigrant business owner is used as a synonym for an immigrant entrepreneur. Most immigrants are involved in small and medium enterprises. The terms entrepreneurship and small and medium enterprises (SME) are often used interchangeably in many studies conducted in the field of entrepreneurship (Agupusi 2007).

Thechatkerng (2012) points out that the theories of immigrant entrepreneurship include Middleman minority theory, the Blocked mobility theory, the Ethnic enclave economy theory, and Interactive theory. The Middleman minority theory can be explained by the role that minority groups play an intermediary between producers of the dominant group and minority customers in different societies. According to the Blocked mobility theory, immigrant entrepreneurship results from a context of disadvantage. A portion of immigrant workers are subject to labour market disadvantage. Immigrants experience disadvantages related to employment in the primary labour market, compared to the native born. The Ethnic enclave economy theory suggests that that most immigrants cannot escape from the bottom of general labour market without the ethnic enclave economy. Immigrants of the same ethnicity tend to gather around certain locations for their residence and business. The Interactive theory suggests that social and human networks contribute significantly to immigrant entrepreneurship.

\subsection{Entrepreneurial orientation and business performance}

Covin and Lumpkin (2011) point out that entrepreneurial orientation (EO) is a process through which individuals in an established firm pursue entrepreneurial opportunities to innovate without regard to the level and nature of currently available resources. EO is a way to act entrepreneurially within an established organisation. The dimensions of EO include autonomy, innovativeness, risk taking, proactiveness, and competitive aggressiveness (Van Geenhuizen et al. 2008). According to Covin and Wales (2011), the theoretical foundation of EO research can be traced to the work of Mintzberg (1973), Khandwalla (1976, 1977), Miller (1983) Covin and Slevin (1989), Miller and Friesen (1982) and Lumpkin and Dess (1996). Mintzberg (1973) suggests three modes of strategy-making: the planning, the adaptive and the entrepreneurial. The planning mode involves systematic information gathering for situational analysis generating alternate strategies and selection of appropriate strategy. The adaptive mode focuses on reactive solutions than proactive search for new opportunities. The entrepreneurial mode is based on active search for entrepreneurial opportunities and growth. Khandwalla (1976/1977) points out that entrepreneurial management style refers to bold, risky and aggressive 
approach to decision-making in contrast to a more cautious stability-oriented approach. Covin and Slevin (1989) find that firms operating in hostile competitive environments, characterised by intense rivalry among firms tend to adopt innovations with greater frequency than firms operating in more benign competitive settings. Miller (1983) observes that an entrepreneurial firm is one that engages in product market innovation, undertakes somewhat risky ventures, and is first to come up with proactive innovations, beating competitors to the punch. Miller (1983) used the dimensions of innovativeness, risk taking and proactiveness to characterize and test entrepreneurial orientation. Lumpkin and Dess (1996) expanded the numbers of dimensions that characterise EO to five by adding competitive aggressiveness and autonomy. Competitive aggressiveness refers to how firms relate to competitors in the market place. Autonomy refers to the key independent actions of an individual in bringing forth an idea and vision and carrying it through to completion.

Haung et al. (2011) note that firms that are proactive and competitively aggressive have forward-looking, opportunity seeking perspective. Proactiveness is important in establishing links and networks with the various sources of finance. Li et al. (2008) and Mukiri (2011) find that firms that have an EO strategic focus may be able to access debt capital due to better relationships with the providers of debt capital. Access to capital can improve firm performance. Aktan et al. (2008) find that EO activities in firms have resulted in diversified products and markets, as well as being instrumental to producing impressive financial results. EO is also positively linked to intangible outcomes, like knowledge, skill development, and job satisfaction. Awang et al. (2010) point out that the ability of a firm to stay competitive is directly related to a firm's intensity to take calculated risks. Fairoz et al. (2010) point out that innovation in the firm of new products, services and processes can lead to sustainable competitive advantage. Zampetakis et al. (2011) find that firms with a more entrepreneurial orientation (EO) perform better than firms that are not. Van Geenhuizen et al. (2008) note that EO can help a firm to create and sustain competitive advantage in the marketplace. Studies such as Wiklund and Shepherd (2005), Callaghan and Venter (2011), Farrington and Hove (2011) and Fatoki (2012) find a positive relationship between entrepreneurial orientation and business performance.

\section{Research Methodology}

The survey was conducted in the Johannesburg Central Business District in Gauteng province of South Africa. The area is suitable for the study because of the high number of immigrant entrepreneurs. The study focused on immigrant entrepreneurs from West Africa specifically, Nigerians, Ghanaians and Senegalese. The empirical approach consists of data collection through the use of self-administered questionnaire. Because of the difficulty of obtaining the population of immigrant-owned businesses in the study area, purposive and snowball sampling methods were used. The study focused on immigrant entrepreneurs that are business owners in the retail sector and have been in existence for at least five years. The questionnaires were given to the owners of the business to complete. Owners were assured of confidentiality with regard to the data collected. Both Likert scale questions and dichotomous questions were used to elicit responses from the respondents. A pilot study was conducted on the survey instrument used in this research with ten immigrant entrepreneurs in order to ensure face and content validity.

According to Covin and Wales (2011), there are four main models to measure entrepreneurial orientation. These are: (1) the Miller/ Covin and Slevin (1989) EO scale; (2) an alternative first-order reflecting scale corresponding to Miller's (1983) composite view of EO (3) the Hughes and Morgan (2007) EO scale; and (4) a "Type 11" second-order formative EO scale (that is, reflective first order, formative second order). In the Miller/Covin and Slevin (1989) scale, EO is measured as a basic, uni-dimensional strategic orientation and the nine items of the Miller/Covin and Slevin scale are jointly aggregated at the model's initial and only step. The alternative first order reflective scale of EO stays true to Miller's (1983) original three-sub-dimension composite view of the EO construct. The Hughes and Morgan (2007) EO scale recognises the multi-dimensionality of the EO construct. EO is not defined as a linear sum of its five sub-dimensions' measures. In addition, EO is not modelled as an aggregated or higher -order empirical construct. The final type of measure of EO is the "Type 11" second-order formative EO scale. Such a scale could be constructed based on the overall pool of items proposed by Hughes and Morgan (2007) scale for measuring EO. The five scales pertaining to EO's sub-dimensions could be used to create latent factors which would then be treated as formative indicators of the secondorder construct. This study used the Miller/Covin and Slevin (1989) scale to measure EO. Five point Likert scale ranging from " 1 strongly disagree to 5 strongly agree" was used to measure the entrepreneurial orientation of immigrant entrepreneurs. The Cronbach's alpha of the scale used to measure entrepreneurial orientation is 0.72 . This indicates an acceptable level of reliability. Descriptive statistics were used for data analysis. 


\section{Results and Discussions}

Out of 82 questionnaires distributed, 34 were returned. This gives a response rate of $41.4 \%$. 25 respondents were male and 9 female. Table 1 depicts the summary of the descriptive statistics for entrepreneurial orientation items.

Table 1: Descriptive statistics for the measures of entrepreneurial orientation

\begin{tabular}{|l|c|c|}
\hline \multicolumn{1}{|c|}{ EO items } & Mean & Standard deviation \\
\hline My enterprise has in the past years introduced many new product lines. & 4.35 & 0.84 \\
\hline My enterprise has in the past years made frequent changes to its product lines. & 4.33 & 0.85 \\
\hline My enterprise gives special attention to research and development. & 2.95 & 0.92 \\
\hline In general, my enterprise has the tendency to be ahead of others in introducing new products. & 4.01 & 0.91 \\
\hline In dealing with competition, my firm often try to initiate actions to competitors for which competitors respond. & 3.98 & 0.90 \\
\hline My enterprise acts boldly in order to achieve objectives. & 3.68 & 0.93 \\
\hline My enterprise typically adopts bold aggressive posture in exploring potential opportunities. & 3.62 & 0.92 \\
\hline My firm has a strong preference for high risk projects with chances of high return. & 3.21 & 0.93 \\
\hline
\end{tabular}

The results as depicted by Table 1 indicate that immigrant entrepreneurs are adept at introducing new product lines and also making changes to the product line. In addition, immigrant entrepreneurs are fairly involved in research including competitive intelligence activities. The results indicate that immigrant entrepreneurs are on the average innovative. Immigrant entrepreneurs tend to introduce new products and also make frequent changes to their product lines. According to Marques and Ferreira (2009), the capacity of a firm to be innovative is one of the major aspects leading to competitive advantage. Under the current market condition, which is characterised by saturated demand, a firm's competitiveness relative to other firms is determined more by its innovative capacity than its productivity. Terziovski (2010) finds that innovation positively impacts on the performance of small firms. Fairoz et al. (2010) and Hung and Chiang (2010) point out that innovation of new products, services by a firm can lead to sustainable competitive advantage. Bigliardi (2013) points out that innovation is one of the major sources for gaining a competitive edge in the market for all companies. An increase in the innovation level increases financial performance. Innovation developed in order to meet customers' needs as well as of those developed in order to differentiate products or services from competitors significantly improve financial performance.

The results also suggest that immigrant entrepreneurs are proactive as they have the tendency to be ahead of others in introducing new products. Haung et al. (2011) note that firms that are proactive and competitively aggressive have forward-looking, opportunity seeking perspective. Proactiveness is important in establishing links and networks with the various sources of finance. Access to external finance can positively impact on firm performance. In addition, the results indicate that immigrant entrepreneurs acts boldly in order to achieve objectives, adopts bold aggressive posture in exploring potential opportunities and have a strong preference for high risk projects with chances of high return. Naldi et al. (2007) find that risk taking is one of the vital attributes of successful entrepreneurs. Awang et al. (2010) point out that the ability of a firm to stay competitive is directly related to a firm's intensity to take calculated risks. Haung et al. (2011) note that firms characterised by risk-taking behaviour often make large resource commitments with a view of securing high returns by seizing opportunities in the market place. In addition, entrepreneurs depicting risk-taking behaviour show more willingness to take on risky resources such as external financial capital. The results indicate that immigrant entrepreneurs are innovative, proactive and are also willing to take risk.

\section{Conclusion}

Immigrant entrepreneurs contribute to the growth and development of South Africa. Immigrant entrepreneurship is one of the solutions to poverty, income inequality and unemployment in South Africa. The objective of this study was to measure the entrepreneurial orientation of immigrant entrepreneurs in South Africa. Today's businesses (including immigrantowned businesses) are faced with a rapidly changing and fast-paced competitive environment. To cope with such challenges an entrepreneurial approach to strategy making may be vital for organisational success. Entrepreneurial orientation has emerged as a possible antidote to the problems facing businesses that wish to achieve a sustained competitive advantage. The results designated that immigrant entrepreneurs are on the average innovative. Immigrant entrepreneurs tend to introduce new products and also make frequent changes to their product lines. The results also showed that immigrant entrepreneurs are proactive as they have the tendency to be ahead of others in introducing new 
products. In addition, the results indicated that immigrant entrepreneurs acts boldly in order to achieve objectives, adopts bold aggressive posture in exploring potential opportunities and have a strong preference for high risk projects with chances of high return. A major limitation is the small number of participants in the study. Thus, caution should be excercised in interpreting the findings and in making generalisations. Data collection could be expanded to include a larger sample of immigrant entrepreneurs in South Africa. Other studies with larger samples can investigate the impact of the gender or the level of education on the entrepreneurial intention of immigrant entrepreneurs.

\section{References}

Aaltonen Satu, Akola Elisa (2014), Lack of trust-the main obstacle for immigrant entrepreneurship? [Online] Available: http://pyk2.aalto.fi/ncsb2012/Aaltonen.pdf (March 15, 2014)

Aktan B., \& Bulut C (2008). Financial performance impacts of corporate entrepreneurship in emerging markets: A case of Turkey. European Journal of Economics, Finance and Administrative Sciences, 12: 69-79.

Aguilar, Luis (2013), The Important Role of Immigrants in Our Economy [Online] Available:http://laht.com/article.asp? Articleld=1103740\&Categoryld=13303 (May 2, 2014)

Agupusi, Patricia (2007), Small Business Development and Poverty alleviation in Alexander, South Africa. [Online] Available: http: I/www.P.Agupusi@uea.ac.uk> (October 17, 2010).

Awang, A., Ahmad, Z.A., Asghar, A.R.S., \& Subari K.A (2010). Entrepreneurial orientation among Bumiputera (BSMAEs) in West Malaysia: Policy implication in Malaysia. International Journal of Business and Management, 5(5): 13- 143.

Bhorat, Haroon, \& van der westhuizen, Carlene (2012), Poverty, inequality and the nature of economic growth in south africa [Online] Available:http://www.humanities.uct.ac.za/sites/default/files/image_tool/images/36/DPRU\%20WP12-151.pdf (May 15, 2014).

Bigliardi, B. (2013). The effect of innovation on financial performance: A research study involving SMEs. Innovation: Management, Policy \& Practice, 15(2): 245-256

Callaghan, C. \&, Venter R (2011). An investigation of the entrepreneurial orientation, context and entrepreneurial performance of innercity Johannesburg street traders. Southern African Business Review, 15(1): 28-48.

Collins, J (2008). Immigrant entrepreneurs in Australia: Regulations and responses. In Oliveira, Catarina Reis and Rath, Jan (eds.), Migrações Journal - Special Issue on Immigrant Entrepreneurship, October 2008, n. 3, Lisbon: ACIDI, pp. 49-59

Covin, J.G., \& Slevin D.P (1989). Strategic management of small firms in hostile and benign environments. Strategic Management Journal, 10: 75-87.

Covin, J.G., \& Wales W.J (2011). The measurement of entrepreneurial orientation. Entrepreneurship Theory and Practice, 1(1): 1-26.

Covin, J.G., \& Lumpkin G.T (2011). Entrepreneurial orientation theory and research: Reflections on a needed construct. Entrepreneurship Theory and Practice, 35(5): 855- 872.

Dalhammar Tobias (2004). Voices of Entrepreneurship and Small Business- Immigrant enterprises in Kista. [Online] Available. http://www.diva-portal.org/smash/get/diva2:7559/FULLTEXT01.pdf (March 19, 2014)

Engelen, E (2002). How innovative are Dutch immigrant entrepreneurs?: Constructing a framework of assessment. International Journal of Entrepreneurial Behaviour \& Research, 8( 1/2): 69 - 92

Fairlie, Robert, \& Lofstrom, Magnus (2013), Immigration and Entrepreneurship [Online] Available.http://people.ucsc.edu/ rfairlie/papers/ (May 2, 2014)

Fairoz, F.M., Hirobumi, T., \& Tanaka Y (2010). Entrepreneurial orientation and business performance of small and medium scale enterprises of Hambantota District Sri Lanka. Asian Social Science, 6(3): 34-46.

Farrington Shelley, Matchaba-Hove, Tony (2011), The Influence of Entrepreneurial Orientation on Small Business Success. [Online]Available.: www.saims2011. ukzn.ac.za/Libraries/Final_Programme/Final_SAIMS_Programme_2011.sflb.ashx> (March $15,2011)$.

Fatoki, 0.0 (2012). The Impact of Entrepreneurial Orientation on Access to Debt Finance and Performance of Small and Medium Enterprises in South Africa. Journal of Social Science, 32(2): 121-131

Hung, K.P., \& Chiang Y. H (2010). Open innovation proclivity, entrepreneurial orientation and perceived firm performance. International Journal of Technology Management, 3(4): 257-274

Haung, K.P, Wang, K.U, Chen, K.H, Yien, J.M (2011). Revealing the effects of entrepreneurial orientation on firm performance. A conceptual approach. Journal of Applied Sciences, 11(6): 3049-3052.

Khandwalla, P.N (1976/1977). Some top management styles, their context and performance. Organisation and Administration Sciences, 7: 21-51.

Li, Y., Zhao, Y., Tan, J., \& Liu Y (2008). Moderating effects of entrepreneurial orientation on market orientation performance linkage: Evidence from Chinese small firms. Journal of Small Business Management, 46(1): 113- 133

Lumpkin, G.T, Dess G.G (1996). Clarifying the entrepreneurial orientation construct and linking it to performance. Academy of Management Review, 21(1): 135-172.

Miller, D., Friesen, P.H (1982). Innovation in conservative and entrepreneurial firms: Two models of strategic momentum. Strategic Management Journal, 3(1): 1-25.

Miller, D (1983). The correlates of entrepreneurship in three types of firms. Management Science, 29(7): 770- 791.

Mintzberg, H (1973). Strategy-making in three modes. California Management Review, 16(2): 44-53 
Mukiri, Wagema (2011), Determinants of Access to Bank Credit by Micro and Small Enterprises in Kenya. [Online] Available: www.growinginclusivemarkets.org/media/ publications/determinants of_access_to_bank credit_by_micro_and_small_enterprises_in_kenya.pdf (May 8, 2014).

Naldi, L., Nordqvist, M., Sjöberg, K., \& Wiklund J (2007). Entrepreneurial orientation, risk taking, and performance in family firms. Family Business Review, 20(1):33- 47.

Pendleton, Wade, Crush, Jonathan, Campbell, Eugene, Green, Thuso, Simelane, Hamilton, Tevera, Daniel, De Vletter, Fion (2006). Migration, Remittances and Development in Southern Africa. [Online] Available http://www.africaportal.org/dspace/ articles/migration-remittances-and-development southern- africa (October 19, 2013).

Rauch, A., Wiklund, J., Lumpkin, G.T. and Frese, M. (2009), Entrepreneurial Orientation and Business Performance: An Assessment of Past Research and Suggestions for the Future. Entrepreneurship Theory and Practice, 33(3): 761-787

Statistics South Africa (2014). Quarterly Labour Force Survey. [Online] Available: http: http://beta2.statssa.gov.za/ (June 5, 2014).

Tengeh, R., Ballard, H., \& Slabbert A (2012). Financing the start-up and operation of immigrant-owned businesses: The path taken by African immigrants in the Cape Town metropolitan area of South Africa. African Journal of Business Management, 6(12): 46664676.

Wayland, Sarah, Hamilton, Leah \& Bierling, Gerald (2012). Winning Strategies for Immigrant Entrepreneurship in Five Communities. [Online] Available: http://www.hamilton.ca/NR/rdonlyres/98D76227-C319-4C2C-9021 ((May 8, 2014).

Thechatkerng, P (2012). Thai Immigrants entrepreneurs in New Zealand. International Journal of Accounting and Financial Management, 2: 83-94

Terziovski, M (2010) Innovation practice and its performance implications in small and medium enterprises (SMEs) in the manufacturing sector: a resource-based view. Strategic Management Journal, 31(8): 892-902

Van Geenhuizen, Maurits, Middel Rick, Lassen, Astrid (2008). Corporate Entrepreneurship in SMEs During the Search for Discontinuous Innovations. [Online] Available: http:// v b n . a a u .d k / f i l e s / 14927322 / C o r p o r a t e _ Entrepreneurship in_SMEs_during_the_Search_for_Discontinuous_Innovations.pdf (June 5, 2014)

Vinogradov Evgueni (2008), Immigrant entrepreneurship in Norway. [Online] Available: http://brage.bibsys.no/xmlui/bitstream/handle/ 11250/140348/Vinogradov.pdf?sequence=1 (May 5, 2014)

Wiklund, J., \& Shepherd, D. (2005). Entrepreneurial orientation and small business performance: a configurational approach. Journal of Business Venturing. 20(1), 71-89.

Zampetakis, L.A., Vekinia, M., \& Moustakis A.V (2010). Entrepreneurial orientation, access to financial resources, and product performance in the Greek commercial TV industry. The Service Industries Journal, 31(6): 897-910 